\title{
Histopathological lesions of molluscs in the harbour of Norderney, Lower Saxony, North Sea (Germany)
}

\author{
Burkard Watermann • Anja Thomsen • \\ Heike Kolodzey • Bernd Daehne • Maike Meemken • \\ Ute Pijanowska $\cdot$ Gert Liebezeit
}

Received: 2 July 2007 / Revised: 6 December 2007 / Accepted: 7 January 2008 / Published online: 5 February 2008

(C) Springer-Verlag and AWI 2008

\begin{abstract}
During a combined research project at several stations along the Lower Saxony coast (German North Sea) antifouling biocides were analysed in water, sediment and biota. Pathological alterations in blue mussel, Pacific oyster and periwinkle found in the harbour of Norderney and a reference station are presented here and discussed on the background of chemical analyses. The molluscan species from the reference station Borkum East flat did not show any pathological effects in central organs, except those provoked by an infestation in the gastro-intestinal tract by the copepod Mytilicola intestinalis and trematode larvae. In most animals, the metacercaria were found in the interstitial tissue without any inflammatory reaction. In a minor number of specimens, an inflammatory reaction in the mucosa and sub-mucosa of the intestine occurred in association with Mytilicola infestation. These reactions may be evoked through mechanical irritation of the gut epithelium, metabolic products of the parasites or invading bacteria. In contrast to the observed pathological changes of mussels, oysters and periwinkles in Norderney harbour were not found to be associated with parasitic infestation. The most prominent pathological alterations were observed in the
\end{abstract}

Communicated by H.-D. Franke.

B. Watermann $(\square) \cdot$ A. Thomsen $\cdot$ H. Kolodzey LimnoMar, Bei der Neuen Münze 11, 22145 Hamburg, Germany

e-mail: watermann@limnomar.de

B. Daehne $\cdot$ M. Meemken

LimnoMar, Am Hafen 10, 26548 Norderney, Germany

e-mail: daehne@limnomar.de

U. Pijanowska $\cdot$ G. Liebezeit

Forschungszentrum Terramare, Schleusenstr. 1,

26382 Wilhelmshaven, Germany

e-mail: gert.liebezeit@terramare.de digestive system and in the gonad. In the gastro-intestinal tract inflammatory reactions, atrophy and necrosis of tubules in the mid gut gland were most pronounced in spring at the beginning of the pleasure boat season in the Pacific oyster and to a minor degree in the blue mussel and the periwinkle. The latter displayed additional inflammatory and necrotic processes in the gills. Especially in the gonad, an elevated resorption rate of gametes was present in the Pacific oyster and in the periwinkle. In addition, impact of organotin compounds was reflected in an intersex index of up to 1.4 in Littorina littorea in coincidence with masculinization of the reproductive organs.

Keywords Molluscs · Mytilus edulis $\cdot$ Littorina littorea . Crassostrea gigas $\cdot$ Histology $\cdot$ Antifouling biocides . Endocrine active compounds

\section{Introduction}

In October 2001, the "International Convention on the Control of Harmful Anti-Fouling Systems" has been adopted, which will come into force by September 2008. A total ban on the sale, application and use of organotin compounds as antifouling biocide (new application since 2003, total ban by September 2008) is the aim of this convention. Although Germany did not ratify this convention, the use of organotin in Germany has been stopped since then. A variety of inorganic (copper, zinc) and organic ( $s$-triazines, dimethylurea, dithiocarbamates, isothiazolinone, etc.) antifouling biocides are in use which will be reviewed by comprehensive dossiers and eventually be approved according to the EU-Biocidal Products Directive, presumably by 2008 . Some of them are of concern as their persistence, bioaccumulative properties and ecotoxicological effects may pose 
Fig. 1 Sampling stations for histological investigations at Borkum and Norderney (arrows)

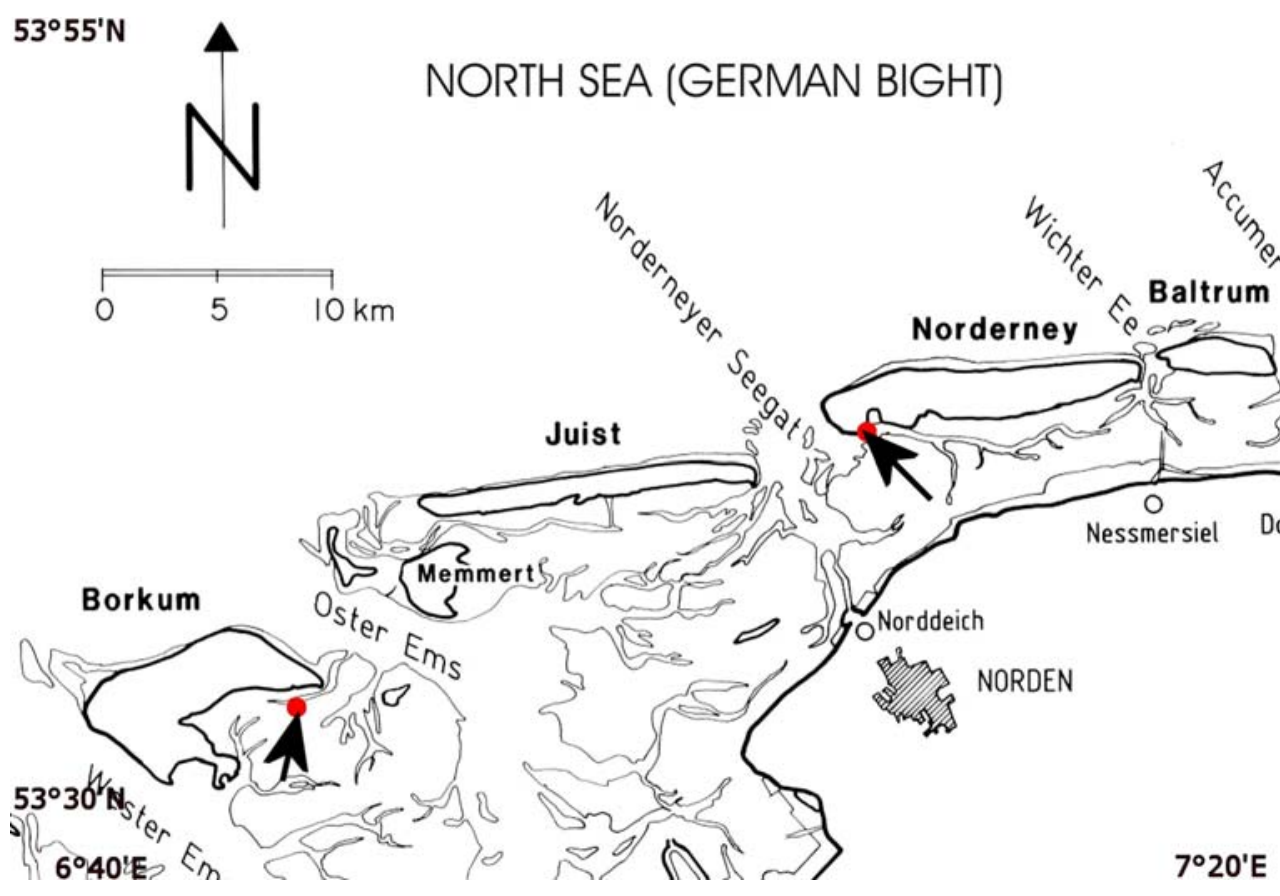

harm to the marine environment (Konstaninou and Albanis 2004). In European countries such as UK, Sweden and Denmark, single biocides have been prohibited for several years due to national approval procedures (Watermann and Gnass 2006; Cresswell et al. 2006).

So far there is lack of information on the contamination and biological effects of inorganic and organic antifouling biocides in use in the harbours of Lower Saxony along the North Sea coast. During a combined research project at several stations, antifouling biocides were analysed in water, sediment and biota (Liebezeit et al. 2006). Pathological alterations in blue mussel, Pacific oyster and periwinkle found in the harbour of Norderney and a reference station are presented here and discussed in the background of the chemical analyses.

\section{Methods}

The investigation on the contamination of the coast of Lower Saxony, German North Sea, referred to those harbours and mudflats where data about residues in water and sediment exist and effective studies of antifouling biocides already had been performed in previous years.

Sampling of sediments and biota for the analysis of Diuron, Irgarol and copper was performed in 2003 and 2004, at the following harbours: Norddeich, Norderney, Greetsiel, Dornumersiel, Bensersiel, Neuharlingersiel, Horumersiel, Hooksiel, Wilhelmshaven-Nassau (Liebezeit et al. 2006).

In August and October 2003, as well as in April and May 2004, samples were taken for histological analysis in the western Lower Saxony Wadden Sea off the island Borkum as reference station (Fig. 1) and at four locations in the harbour of Norderney. A total of 226 mussels and snails were collected and processed for histology.

The snails were narcotized ( $7 \% \mathrm{MgCl}_{2}$ in distilled water) to separate the soft body without damage from the shell. The mussels and oysters were opened with an oyster knife and the soft body thoroughly separated from the shell. The shell thickness index (STI) was determined according to Dyrynda (1992). The soft body was fixed in Bouin's fluid for $24 \mathrm{~h}$, washed and stored in $80 \%$ ethanol. After dehydration, the fixed animals, or gonadal tissues, were embedded in paraffin (Shandon, Hyper Center)) and cut with a rotary microtome (Microm) in serial sections of 2-3 $\mu \mathrm{m}$. For routine histology, sections were stained with haematoxylin and eosin (Romeis 1989).

\section{Results}

Mytilus edulis

\section{Borkum East flat}

A total of 27 animals with shell lengths of $43-61 \mathrm{~mm}$, collected in spring and late summer were histologically evaluated (Table 1). In April, the gonad was in maturing stage. Some females had already spawned. In August, all mussels displayed a spawned gonad in regeneration. In one specimen, a disturbance of spermatogenesis covering about 20 tubuli was noted. In the affected tubuli, atrophic gamete 
Table 1 Mytilus edulis, Crassostrea gigas, Littorina littorea, stations, sampling time, number samples, shell length

\begin{tabular}{|c|c|c|c|c|c|}
\hline Station & Sampling time & Species & $\begin{array}{l}\text { Number of } \\
\text { samples }\end{array}$ & $\begin{array}{l}\text { Shell length }(\mathrm{mm}) \\
\text { minimum-maximum }\end{array}$ & $\begin{array}{l}\text { Shell length } \\
(\mathrm{mm}) \text { mean } \pm \mathrm{SD}\end{array}$ \\
\hline \multirow[t]{6}{*}{ Borkum East flat } & \multirow[t]{3}{*}{ August 03} & Mytilus edulis & 12 & $43-59$ & $50.5 \pm 4.95$ \\
\hline & & Crassostrea gigas & 10 & $70-108$ & $82 \pm 12.31$ \\
\hline & & Littorina littorea & 24 & $13-19$ & $15.6 \pm 1.77$ \\
\hline & \multirow[t]{3}{*}{ April 04} & Mytilus edulis & 15 & $49-61$ & $54.1 \pm 3.35$ \\
\hline & & Crassostrea gigas & 15 & $8-39$ & $18.3 \pm 9.62$ \\
\hline & & Littorina littorea & 15 & $15-21$ & $17.2 \pm 1.42$ \\
\hline \multirow[t]{10}{*}{ Norderney harbour } & \multirow[t]{2}{*}{ August 03} & Mytilus edulis & 10 & $34-48$ & $40.8 \pm 4.50$ \\
\hline & & Crassostrea gigas & 10 & $45-62$ & $54.8 \pm 5.08$ \\
\hline & August 03 & Littorina littorea & 9 & $19-24$ & $20.8 \pm 1.70$ \\
\hline & October 03 & Crassostrea gigas & 21 & $43-94$ & $65.6 \pm 14.07$ \\
\hline & \multirow[t]{3}{*}{ April 04} & Mytilus edulis & 15 & $43-53$ & $48.7 \pm 2.69$ \\
\hline & & Crassostrea gigas & 15 & $70-120$ & $81.1 \pm 12.73$ \\
\hline & & Littorina littorea & 10 & $23-26$ & $24.2 \pm 0.92$ \\
\hline & \multirow[t]{3}{*}{ May 04} & Mytilus edulis & 11 & $37-52$ & $43.7 \pm 4.41$ \\
\hline & & Crassostrea gigas & 17 & $49-92$ & $69.5 \pm 10.47$ \\
\hline & & Littorina littorea & 20 & $18-26$ & $21.7 \pm 2.49$ \\
\hline
\end{tabular}

stages were present and a number of cells resembling protozoans, possibly haplosporidians. Haemocytes had infiltrated these tubules and phagocytized gametes as well as protozoans. Some tubuli were entirely filled with haemocytes or fibroblasts after the breakdown of the tubule membrane.

Forty-one percent of the mussels were infested with metazoan parasites and displayed associated lesions of the intestine. The copepod Mytilicola intestinals caused an inflammatory reaction in the mucosa and sub-mucosa with massive infiltration of haemocytes. Haemocytes were present as extensive aggregates in the sub-mucosa and had infiltrated the mucosa by multifocal nests. Eosinophilic and hyaline haemocytes with phagocytotic activity were found in nests, harbouring lipo-pigments in their cytoplasm. Circulating haemocytes, granule cells of the ventricle as well as phagocytes in the kidney contained lipo-pigments in mussels infested by Mytilicola intestinalis.

Metacercaria of trematodes were observed in $11 \%$ of the animals in the connective tissue and in the gills without any adjacent inflammatory reaction. In the gills, focal necrosis of secondary lamellae in connection with the presence of ciliates (presumably Ancestrum sp.) was observed in $22 \%$ of the mussels.

Apart of parasite-associated lesions, the respiratory, digestive, cardio-vascular and the excretory systems as well as the gonad were-of normal appearance.

\section{Norderney harbour}

At this station 36 animals with shell length of $34-53 \mathrm{~mm}$ were collected in late summer 2004 and spring 2003, for histological evaluation (Table 1). Most of the females had spawned in April and May, in only a few animals the gonads were still in a mature stage. In April, 27\% of the animals showed enhanced resorption of gametes with haemocyte infiltration and lipo-pigments.

The central organs displayed parasite-associated lesions as well as several pathological disorders. Aggregations of haemocytes in the sub-mucosa and nests of infiltrated haemocytes in the mucosa were noticed in $92 \%$ of blue mussels. In the gills of $14 \%$ of the specimens, focal haemocyte infiltration into the epithelium of secondary lamellae was present. The cytoplasm of phagocytizing haemocytes contained abundant lipo-pigments. In $72 \%$ of animals, a dilatation and congestion of vessels around the mid gut gland and the gonad occurred. Mytilicola-associated lesions in the digestive system were dominant in $69 \%$ of mussels infested by this parasite.

\section{Crassostrea gigas}

\section{Borkum East flat}

Altogether, 25 animals with shell length of 8-108 mm were collected in spring 2003 and late summer 2004, for histological evaluation (Table 1). The gonads of both sexes were maturing in April and were fully mature in August with one hermaphroditic individual. Focal haemocyte infiltration in the mucosa of the gastro-intestinal tract as well as an increased number of epithelial mucous cells was recorded in $12 \%$ of oysters. Parasites could not be detected in the afflicted tissues. 


\section{Norderney harbour}

In total, 63 oysters with shell length of 8-120 mm were collected in late summer and autumn 2003, and in spring 2004, for the histological evaluation (Table 1). Out of 63 oysters, 33 males, 28 females and 2 hermaphrodites were encountered. The gonads of both genders were in mature. However, $30 \%$ of males showed a disturbance of spermatogenesis. With respect to the to maturation stage of the gonad, remarkable differences between the genders were recorded. While all females had spawned and the gonads were in the stage of regeneration, most males had still a mature gonad; only $10 \%$ of males had already spawned.

The most striking pathological alterations were recorded in the intestine and the gonad over the seasonal cycle. In August and October 2003, the overall appearance of the mid gut gland of all animals was that of tubulus epithelium of reduced height. In $23 \%$ of the oysters an atrophy of the epithelium occurred. In all specimens a sub-epithelial haemocyte infiltration in the interstitial storage tissue of the mid gut gland was noticed along with a multifocal accumulation of lipo-pigments in haemocytes. Parasites could not be detected. In parallel, the same specimens displayed massive lipo-pigment deposits in granular cells of the ventricle.

In October 2003, deviations from the normal appearance of the intestine occurred exclusively in association with trematode parasites. In $25 \%$ of oysters haemocyte infiltration in the sub-mucosa in the periphery of metacercaria was noticed.

Additional sampling in the harbours was conducted in April and Mai 2004 to observe the situation in the beginning of the pleasure boat season when inputs of antifouling biocides into the water are elevated. Pathological alterations were observed in the gills, the digestive system and the gonad. In $28 \%$ of oysters, focal haemocyte infiltration and a distal dilatation of secondary lamellae of gills occurred. In one animal a granuloma at the gill base was detected.

In $32 \%$ of animals, increased numbers of mucous cells were found in the mucosa of the intestine and in the tubulus epithelium of the mid gut gland. The mucosa cells of all oysters contained brown to yellow lipo-pigment deposits. Intraepithelial and sub-epithelial haemocyte infiltration was found in the stomach and in the intestine in $15 \%$ of the specimens. In several individuals the infiltration was so intense that it resulted in haemocyte congestion in secondary tubuli of the mid gut gland (Fig. 2). In April the gonads of both sexes were predominantly in the ripening phase, to a minor degree in the regeneration phase. In $18 \%$ of oysters a moderate to strong resorption of gametes in connection with haemocyte infiltration and phagocytosis in the follicles of the female gonad and in the hermaphroditic gonad was visible (Fig. 3).

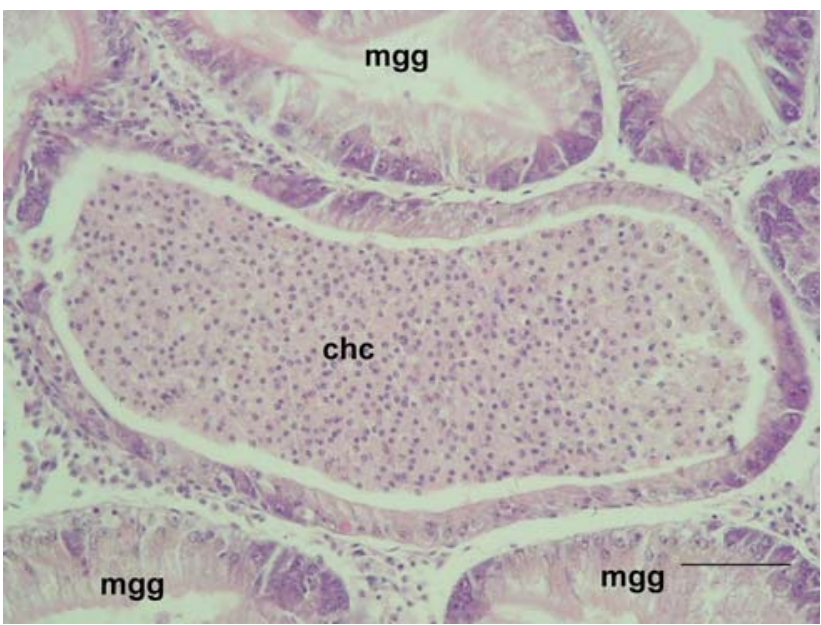

Fig. 2 Crassostrea gigas, Norderney harbour; massive haemocyte congestion (chc) in secondary duct of mid gut gland ( $m g g)$; bar $25 \mu \mathrm{m}$, HE staining

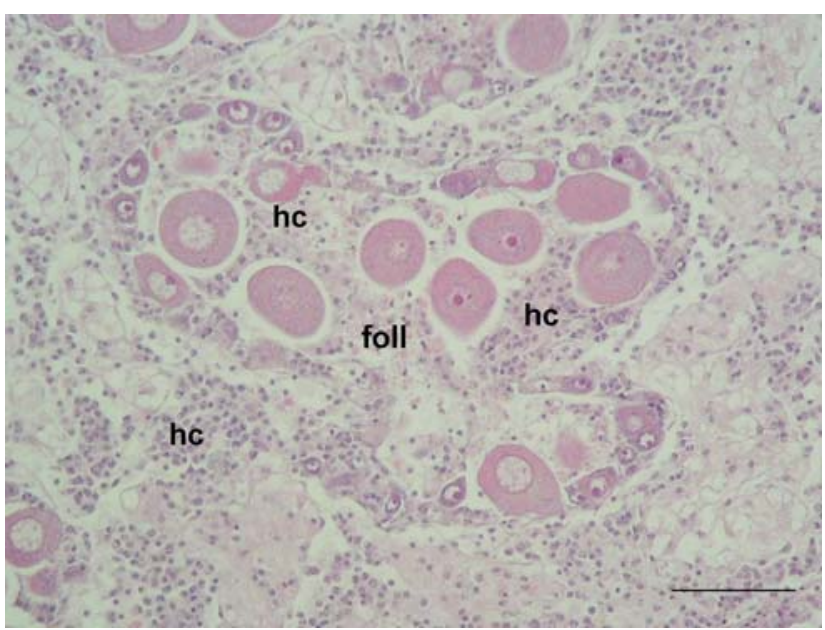

Fig. 3 Crassostrea gigas, Norderney harbour; massive haemocyte infiltration $(h c)$ and resorption in a follicle $(f o l l)$ of female gonad; bar $25 \mu \mathrm{m}$, HE staining

In one animal metacercaria of trematodes were present.

In contrast to the observations made in summer and autumn 2003, in May 2004 in $82 \%$ of oysters shell malformations as chambering occurred. It was characterized by a jelly liquid deposition between the shell layers (Fig. 4). The shell layers were very thin and fragile. The chambering of oyster shells resulted in ball-shaped shells. The average STI was 8.5 (minimum 6.8 , maximum $10.1 ; N=17$ ), slightly beneath the normal value of 10 .

\section{Littorina littorea}

In August 2003 and in April/May 2004 a total of 78 periwinkles with shell height of $13-26 \mathrm{~mm}$ was collected at Borkum and Norderney (Table 1). 


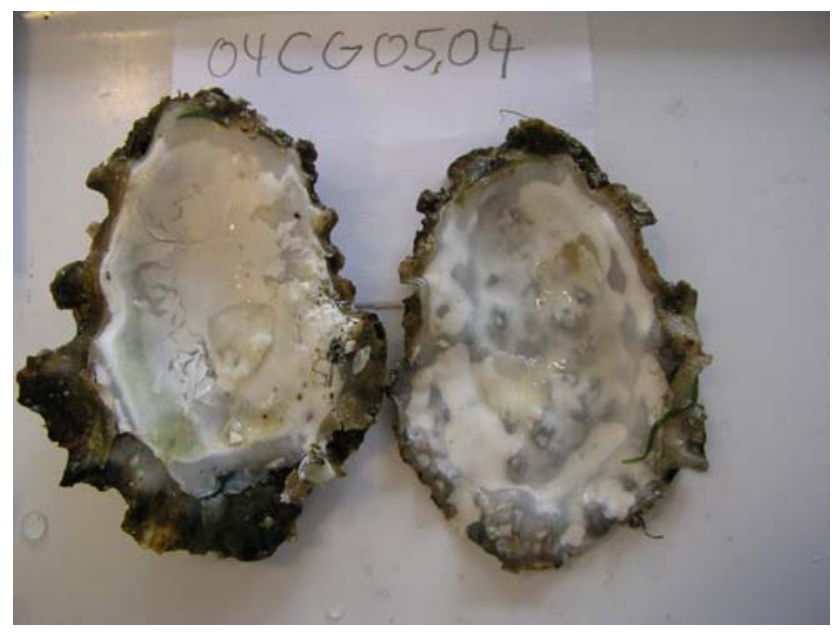

Fig. 4 Crassostrea gigas; shell chambering of individual from Norderney harbour

\section{Borkum East flat}

In August the gonad of all females was in a mature stage or already spawned, whereas the gonads of all males were ripe but not yet spawned (Fig. 5). In April both sexes possessed a mature gonad. The intersex index of females in August was 0 and in April 0.08. The albumen gland displayed the normal appearance according to the reproductive season (Fig. 6).

The main organs of Littorina were of normal appearance without pathological alterations, different from those associated with trematode parasites. In April, $20 \%$ of periwinkles were infested with trematode larvae in interstitial tissue of the mid gut gland, gonad and kidney (Table 2).

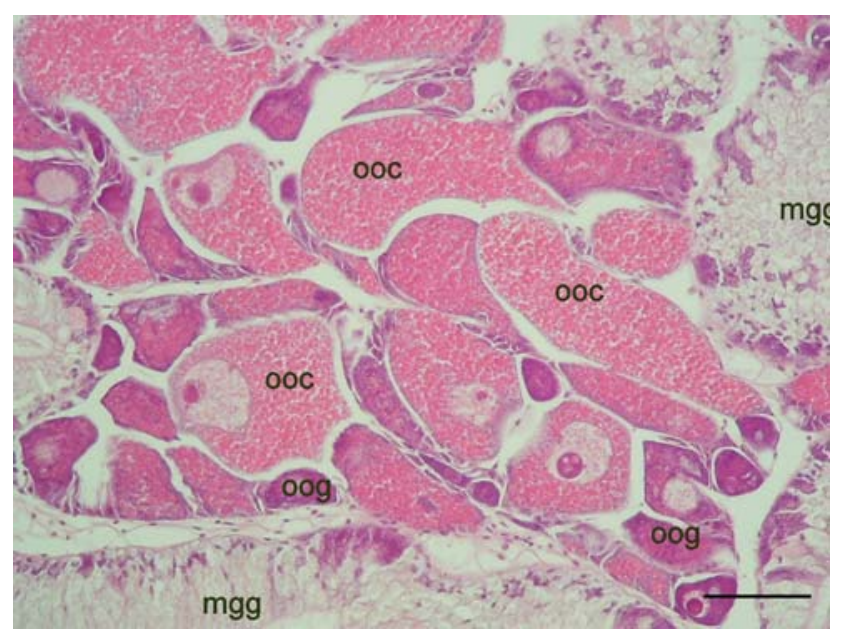

Fig. 5 Littorina littorea, Borkum; gonad in active oogenesis, oogonia (oog), oocytes (ooc), mid gut gland (mgg), bar $50 \mu \mathrm{m}$, HE staining

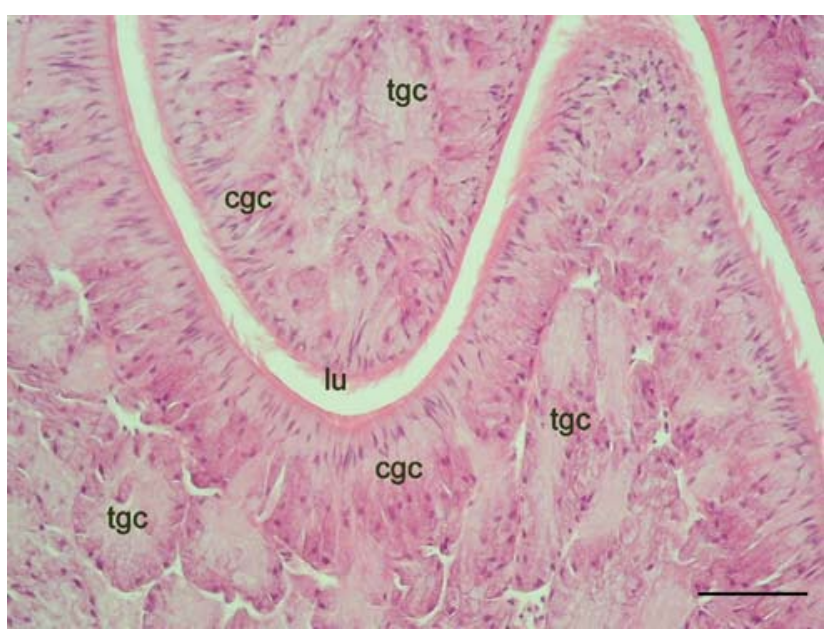

Fig. 6 Littorina littorea, Borkum; albumen gland, tubular gland cells $(\operatorname{tgc})$, cluster gland cells $(c g c)$, lumen $(l u)$ of oviduct; bar $50 \mu \mathrm{m}, \mathrm{HE}$ staining

Table 2 Intersex of Littorina littorea at the reference station Borkum East flat and in Norderney harbour

\begin{tabular}{llll}
\hline Station & $\begin{array}{l}\text { Number of } \\
\text { females }\end{array}$ & $\begin{array}{l}\text { Intersex } \\
\text { index }\end{array}$ & $\begin{array}{l}\text { Encountered } \\
\text { intersex stages }\end{array}$ \\
\hline $\begin{array}{l}\text { Borkum East flat } \\
\text { August 2003 }\end{array}$ & 14 & 0 & \\
$\begin{array}{l}\text { April 2004 } \\
\text { Norderney harbour }\end{array}$ & 14 & 0.07 & 0, I \\
$\begin{array}{l}\text { August 2003 } \\
\text { April 2004 }\end{array}$ & 6 & & \\
May 2004 & 6 & 0.3 & 0, I \\
\hline
\end{tabular}

Norderney harbour

For the histological evaluation, 39 snails were collected at four locations in the Norderney harbour. In both sexes, most specimens displayed disturbances in gametogenesis. In August, the gonad of both genders was in the ripening stage, instead of being fully ripe, indicating an extensive delay in gonad maturation.

In April/May the male gonad was in the ripening stage and to a minor degree in the ripe stage. In $69 \%$ of female snails, a massive resorption of oogonia and oocytes occurred along with haemocyte infiltration and deposits of lipo-pigments in the follicle epithelium (Fig. 7). A fibrosis of numerous follicles per gonad was observed in $18 \%$ of snails. In parallel, the albumen gland displayed extended secretory ducts (Fig. 8).

Additional morpho-pathological alterations were observed in April. Along with the opening of the Bursa copulatrix, the capsule gland of several females was splitoff corresponding to intersex stages I and II, and resulting 


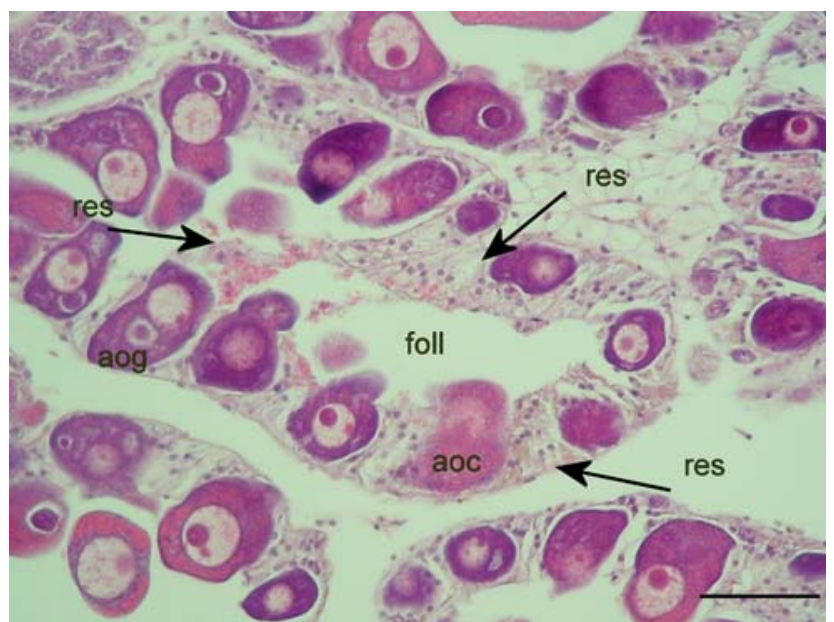

Fig. 7 Littorina littorea, Norderney harbour; female gonad with follicles (foll), follicle epithelium (arrows) in enhanced resorption (res) of atrophic oogonia (aog) and oocytes (aoc); bar $50 \mu \mathrm{m}$, HE staining

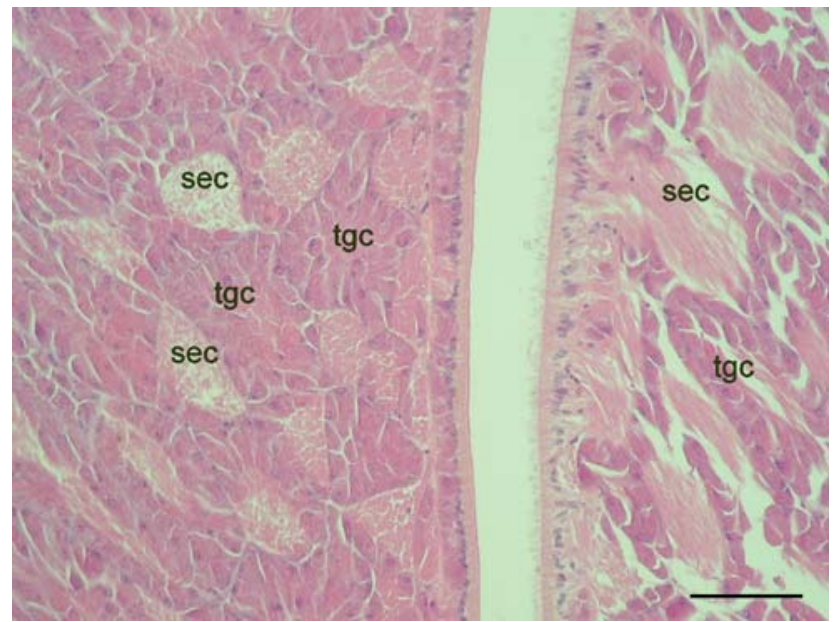

Fig. 8 Littorina littorea, Norderney harbour; albumen gland with tubular gland cells $(\operatorname{tgc})$ and extended secretory ducts (sec); bar $50 \mu \mathrm{m}$, HE staining

in an overall intersex index of 0.5. In May, more advanced masculinization of the female pallium gland complex (yelly-, capsule-, albumen gland) in $42 \%$ of animals was recorded, in correspondence with intersex stages I, II and III. The overall intersex index amounted to 1.42 .

In August, massive resorption of oogonia and oocytes occurred in the majority of the follicles in $83 \%$ of females (Fig. 9). The size of affected follicles was clearly reduced. The histological alterations corresponded with the observed morphological deviations in the female reproduction tract. In August 2003, 30\% of female snails displayed an opening of the Bursa copulatrix corresponding to the intersex stage I. The intersex index amounted to 0.33 . Females with an intersex stage II displayed an albumen gland with focal atrophic areas (Fig. 10). Females with an intersex stage III

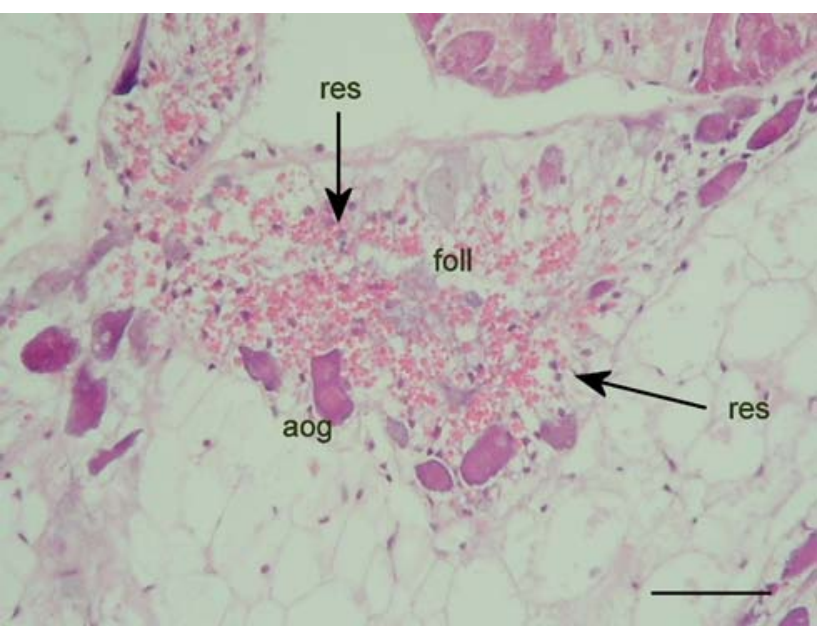

Fig. 9 Littorina littorea, Norderney harbour; female gonad with follicles $($ foll $)$ in intense resorption of atrophic oogonia (aog), (res, arrows) resorbing follicle epithelium with pink vitelline granules; bar $50 \mu \mathrm{m}$, HE staining

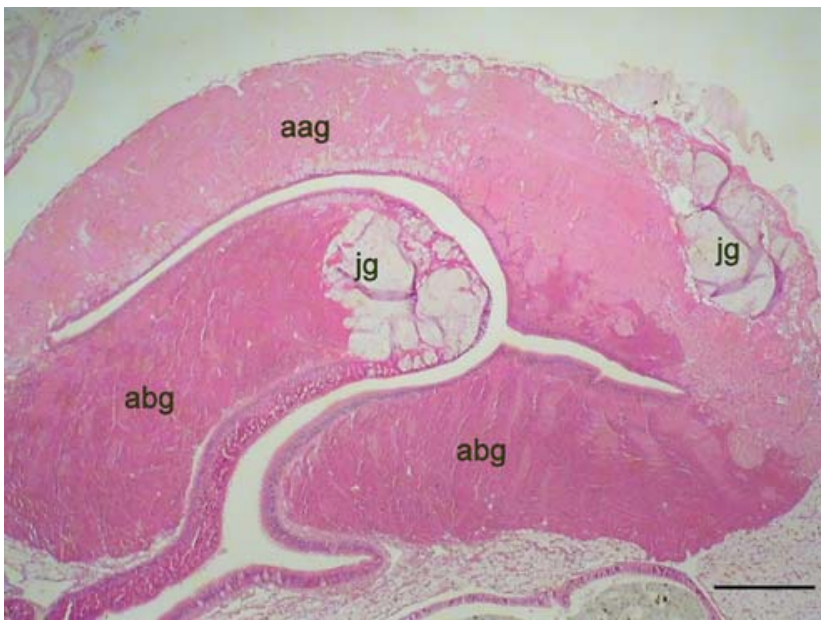

Fig. 10 Littorina littorea, intersex stage II, Norderney harbour; albumen gland with normal structure ( $a b g$ ) and atrophic areas ( $a a g)$, jelly gland $(j g)$; bar $1,000 \mu \mathrm{m}$, HE staining

displayed a gonad with strong resorption of oogonia and oocytes (Fig. 11), an albumen gland which was partly (Fig. 12) or completely (Fig. 13) transformed to a prostate, and a reduced capsule gland (Fig. 12).

In May 36\% of males showed a disturbance in spermatogenesis with atrophic tubules accompanied by massive storage of lipo-pigments in the tubulus epithelium. In one male, an arrest in spermatogenesis occurred in several tubules associated with haemocyte infiltration and a dilatation of adjacent vessels. The prostate of single males displayed a hyperplasia of undifferentiated basal cells (Fig. 14).

Whereas in August the digestive system did not show any pathological changes, in April and May several pathological disorders occurred. A focal tubulus necrosis of the mid gut gland was noticed in April in 10\%, and in a 


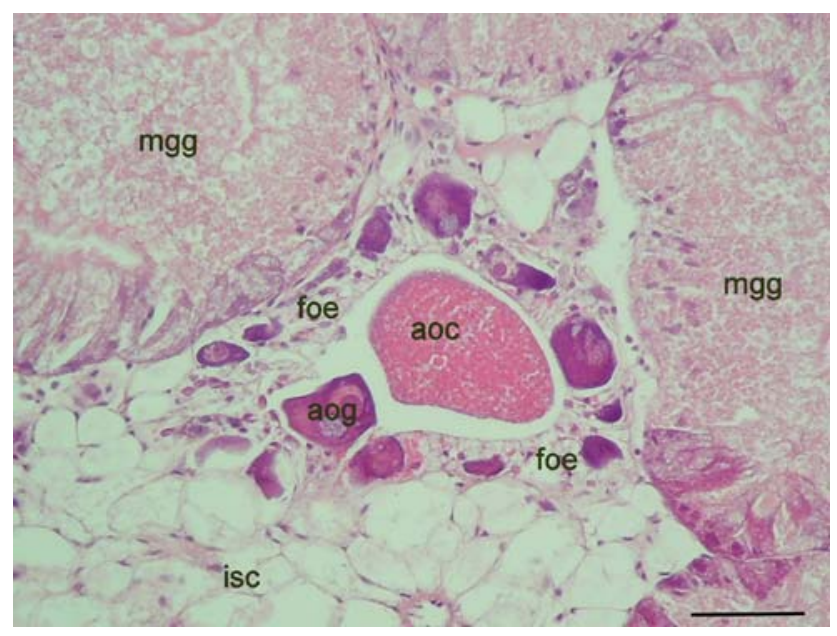

Fig. 11 Littorina littorea, intersex stage III, Norderney harbour; female gonad, atretic follicle with strong resorption of atrophic oogonia $(a \circ g)$ and oocyte $(a o c)$, follicle epithelium (foe), midgut gland ( $m g g)$; bar $50 \mu \mathrm{m}$, HE staining

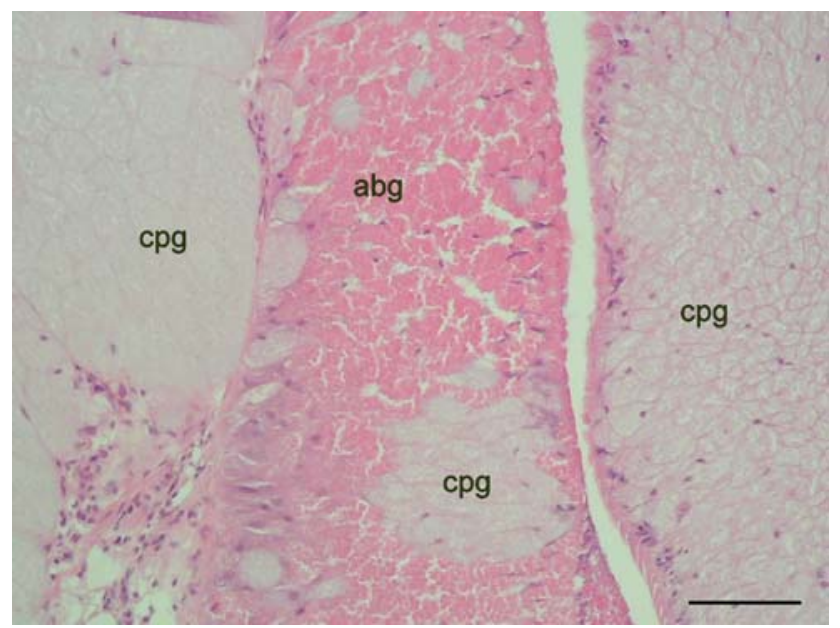

Fig. 12 Littorina littorea, intersex stage III, Norderney harbour; albumen gland $(a b g)$ transformed to prostate, with reduced capsule gland (cpg); bar $50 \mu \mathrm{m}$, HE staining

multifocal pattern in May in $70 \%$ of snails. In parallel, in $33 \%$ of periwinkles, pigment deposits in pore cells between the tubuli of the mid gut gland, in phagocytes of the ventricle and in phagocytes of the kidney were observed.

An infestation with parasites was recorded to a minor degree. In April and May an infestation with Mytilicola intestinalis, indetermined trematode larvae and protozoa in the kidney were encountered.

\section{Discussion}

All three analysed mollusc species from the reference station Borkum East flat did not show any pathological effects in central organs, except for those provoked by an

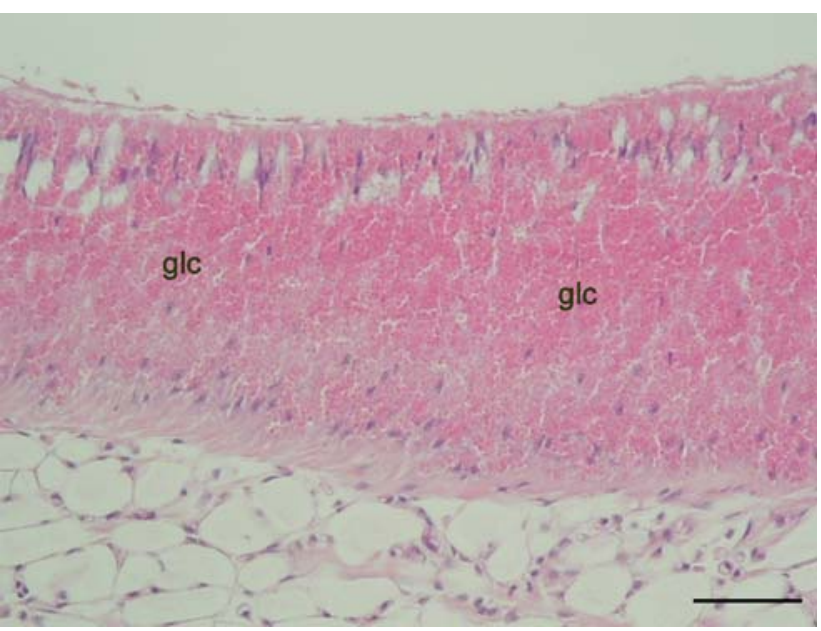

Fig. 13 Littorina littorea, intersex stage III, Norderney harbour; female prostate with differentiated gland cells $(g l c)$; bar $50 \mu \mathrm{m}$, HE staining

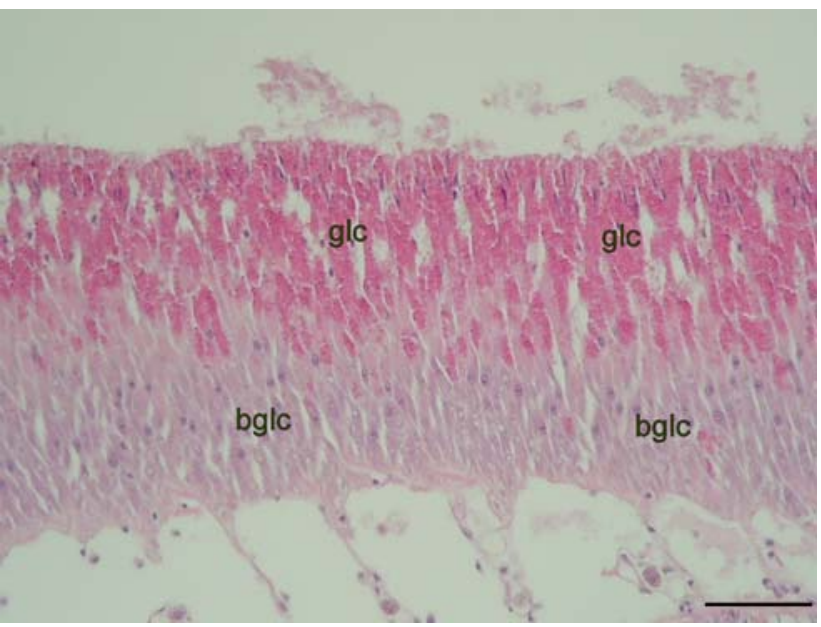

Fig. 14 Littorina littorea, Norderney harbour; male prostate with differentiated gland cells $(g l c)$ and an extended basal layer of undifferentiated gland cells $($ bglc); bar $50 \mu \mathrm{m}$, HE staining

infestation of the gastro-intestinal tract by Mytilicola intestinalis and trematode larvae. In most animals the metacercaria were found in the interstitial tissue without any inflammatory reaction. In a minor number of specimens an inflammatory reaction in the mucosa and sub-mucosa of the intestine occurred in association with Mytilicola infestation. These reactions may be evoked through mechanical irritation of the gut epithelium, metabolic products of the parasites or invading bacteria.

The observed pathological changes of mussels, oysters and periwinkles in Norderney harbour were not found to be associated with parasitic infestation. The most prominent pathological alterations were observed in the digestive system and in the gonad. In the gastro-intestinal tract inflammatory reactions, atrophy and necrosis of tubules in the mid 
gut gland were most pronounced in spring at the beginning of the pleasure boat season in the Pacific oyster and to a minor degree in the blue mussel and the periwinkle. The latter displayed additional inflammatory and necrotic processes in the gills. Especially in the female gonad, increased resorption rates of gametes were present in the Pacific oyster and in the periwinkle.

The chemical analysis of sediments and biota in harbours of Lower Saxony including the Borkum East flat revealed for heavy metals such as copper, zinc and lead, slightly elevated levels above the North Sea background (Liebezeit et al. 2006). The mean sediment content of copper in Lower Saxony harbours was $24.8 \pm 10.8 \mu \mathrm{g} / \mathrm{g}$, being in the range of the background level of the North Sea with $20-30 \mu \mathrm{g} / \mathrm{g}$.

It is known that copper can be ingested and stored in bivalves and gastropods in the gills, haemocytes and pore cells. Pore cells are most abundant in the interstitial storage tissue, in the kidney and in the ventricle of the heart (Soto et al. 1996; Regoli and Orlando 1994). Mussels can excrete copper by incorporation into the byssus threats (Davenport and Redpath 1984). Taking into account the observed copper contents in the harbour sediments, it is very unlikely that the observed pathological effects in the bivalves and gastropods in the harbour of Norderney are related to acute toxic effects of copper.

The pathological alterations, especially the inflammatory reaction in the sub-mucosa of the intestine and the increased resorption in the gonad, were accompanied by an increased deposit of yellow brown lipo-pigments in haemocytes and epithelial cells of follicles and tubules. Haemocytes of bivalves contain phenoloxidase (Caraballal et al. 1997), an enzyme belonging to the prophenoloxidase-system, which plays a role in the unspecific immune reaction of arthropods (Johansson and Söderhäll 1992). As lipopigment-loaded haemocytes can be found more frequently in Norderney harbour than at Borkum, uptake and storage of foreign particles or damage of cells by infectious agents or toxic compounds have to be taken into consideration.

Chemical analysis of the content of the organic antifouling biocides Diuron and Irgarol in harbours of Lower Saxony showed elevated concentration in the harbour sediments compared the reference station Borkum flat. The mean content of Diuron was $115 \pm 93 \mathrm{ng} / \mathrm{g}$ in harbour sediments and $60 \mathrm{ng} / \mathrm{g}$ in sediments of the Borkum flat. The mean content of Irgarol was $6.1 \pm 5.8 \mathrm{ng} / \mathrm{g}$ in harbour sediments and $1 \mathrm{ng} / \mathrm{g}$ in sediments of the Borkum flat (Liebezeit et al. 2006). Regarding the measured contamination of sediments by Diuron and Irgarol cited above, the observed histopathological effects in the Norderney harbour cannot be attributed to acute toxicity of this compound: For Diuron, an EC50 value of $1,800 \mu \mathrm{g} / \mathrm{l}$ for adult oysters and $4,800 \mu \mathrm{g} / \mathrm{l}$ for oyster spat was determined. However, the endocrine effects occur at far lower concentration, which is reflected in the Quality Standard of $0.2 \mu \mathrm{g} / 1$ set up in the actual compromise paper in addition to the EU-Water Frame Directive. A similar situation can be stated for Irgarol 1051, which has a relatively high acute toxicity level of 3.2 mg/l (EC50) (Bard and Pedersen 1992; Bard 1997). Again, endocrine effects on the reproductive system could be observed at far lower concentration. In Radix balthica, feminization effects occurred from an Irgarol concentration of $14 \mathrm{ng} / \mathrm{l}$ (unpublished results). The observed atrophic effects in the male gonad of bivalves and gastropods may be associated with endocrine effects of Diuron and/or Irgarol 1051.

The harbour of Norderney is especially suited for field investigations as in addition to some hundred pleasure boats, the floating jetties are coated with antifouling paint.

The Norderney marina is built of floating jetties with a total surface of $450 \mathrm{~m}^{2}$, which are coated with an anticorrosive paint based on epoxy as a base layer. The epoxy paint contains as plasticizer Bisphenol A, which may leach for a certain time (Watermann et al. 2005). As topcoat, an antifouling containing chlorothalonil, Diuron and di-copper oxide has been painted. Bisphenol A and other plasticizers like phtalates with estrogenic potential may play a role as contaminant in harbours. A study of 39 harbours in Japan revealed that approximately $30-40 \%$ of them had sediments contaminated with these substances (Hosokawa et al. 2003).

The high content of antifouling biocides led either to the prohibition or to the restriction of their use on leisure boats in several countries. In the years 1995 to 1997, intensive investigation in Danish marinas and commercial ports has been carried out which revealed high concentrations of antifouling biocides in the sediments. In particular, copper, Diuron and Irgarol 1051 were found in high concentrations. Due to the high values of Irgarol 1051 and Diuron in Danish harbours, both biocides have been prohibited for leisure boats since January 2000 (Lassen et al. 2002).

In 2000, in Sweden, the contamination of water, sediment and biota with copper and organic biocides resulted in a ban to sell antifouling systems containing copper or Irgarol 1051 on the East coast. In UK, since 2001, the use Irgarol 1051 and Diuron on pleasure boats is prohibited, which led to a steep decrease in their concentrations in water at the British South coast.

In contrast, the high intersex index of periwinkles and the shell chambering of the Pacific oyster in combination with the disturbance of female gonad maturation and the atrophy of female accessory sexual glands may be associated with organotin compounds still present in the sediments (Dyrynda 1992; Bauer et al. 1995, 1997). Despite the ban on the use and application of organotin compounds, long-term contamination has to be taken into consideration. The half-life of TBT in deep sediments is estimated to be approximately 90 years (Hosokawa et al. 2003; Viglino 
et al. 2004). Although the harbours along the Lower Saxony coast are dredged every 2 or 3 years, traces of organotin are still present, indicated by elevated intersex indices of periwinkles (unpublished results).

The elevated prevalence of inflammatory and necrotic changes in the digestive tract of periwinkles and mussels encountered in the harbour of Norderney at the beginning of the pleasure boat season may indicate an impairment of the immune system. Adverse effects on the immune system of molluscs can be exerted by a variety of compounds and cannot be attributed to a single factor (Watermann et al. 1996, 1998).

Acknowledgments The authors appreciate the Niedersächsische Wattenmeerstiftung for funding this study. In addition they express their indebtedness to the critics for their useful comments and the reviewer for the recommendations.

\section{References}

Bard J (1997) Supplement 3 to the ecotoxicological evaluation of the antifouling compound 2-(tert-Butylamino)-4 (cyclopropylamino)-6-(methylthio)-1,3,5-triazine, Irgarol 1051. Report 14/9, Nässja Ekotoxkonsult, Åseda, Sweden

Bard J, Pedersen A (1992) Ecotoxicological evaluation of the antifouling compound 2-(tert-Butylamino)-4-(cyclopropylamino)-6(methylthio)-1,3,5-triazine Irgarol 1051. National Chemicals Inspectorate (KEMI), Solna, pp 1-50

Bauer B, Fioroni P, Ide I, Liebe S, Oehlmann J, Stroben E, Watermann B (1995) TBT effects on the female genital system of Littorina littorea: a possible indicator of tributyltin pollution. Hydrobiologia 309: $15-27$

Bauer B, Fioroni P, Schulte-Oehlmann U, Oehlmann J, Kalbfus W (1997) The use of Littorina littorea for tributyltin (TBT) effect monitoring-results from the German TBT survey 1994/1995 and laboratory experiments. Environ Pollut 96:299-309

Caraballal MJ, Lopez C, Azevedo A, Villalba A (1997) In vitro study of phagocytic ability of Mytilus galloprovincialis Lmk. haemocytes. Fish Shellfish Immunol 7:403-416

Cresswell T, Richards JP, Glegg GA, Readman JW (2006) The impact of legislation on the usage and environmental concentrations of Irgarol 1051 in UK coastal waters. Mar Pollut Bull 52:1169-1175

Davenport J, Redpath KR (1984) Copper and the mussel Mytilus edulis L. In: Bolis L, Zadunaisky J, Gilles R (eds) Toxins, drugs and pollutants in marine animals. Springer, Berlin, pp 176-189
Dyrynda E (1992) Incidence of abnormal shell thickening in the Pacific oyster Crassostrea gigas in Poole Harbour (UK), subsequent to the 1987 TBT restrictions. Mar Pollut Bull 24:156-163

Hosokawa Y, Ysui M, Yoshikawa K, Tanaka Y, Suzuki M (2003) The nationwide investigation of endocrine disruptors in sediment of harbours. Mar Pollut Bull 47:132-138

Johansson MW, Söderhäll K (1992) Cellular defense and cell adhesion in crustaceans. Anim Biol 1:97-107

Konstaninou IK, Albanis TA (2004) Worldwide occurrence and effects of antifouling paint booster biocides in the aquatic environment: a review. Environ Int 30:235-248

Lassen C, Skarup S, Mikkelsen SH, Kjolholt J, Nielsen PJ, SamsoePetersen L (2002) Inventory of biocides used in Denmark. Environmental Project No. 585

Liebezeit G, Pijanowska U, Watermann B, Thomsen A, Kolodzey H, Daehne B, Meemken M (2006) Abschlußbericht Untersuchungen zur Kontamination der niedersächsischen Seehäfen mit organischen Antifoulingbioziden, Niedersächsische Wattenmeerstiftung, Wilhelmshaven, Germany

Regoli F, Orlando E (1994) Accumulation and subcelllar distribution of metals $(\mathrm{Cu}, \mathrm{Fe}, \mathrm{Mn}, \mathrm{Pb}$, and $\mathrm{Zn})$ in the Mediterranean mussel Mytilus galloprovincialis during a field transplant experiment. Mar Pollut Bull 28:592-600

Romeis B (1989) Mikroskopische Technik. Urban \& Schwarzenberg, München

Soto M, Cajaraville MP, Angulo E, Marigomez I (1996) Autometallographic localization of protein-bound copper and zinc in the common winkle, Littorina littorea: a light microscopy study. Histochem J 28:689-701

Viglino L, Pelletier E, St-Louis R (2004) Highly persistent butyltins in northern marine sediments: a long-term threat for the Saguenay Fjord (Canada). Environ Toxicol Chem 23:2673-2681

Watermann B, Gnass K (2006) Nachhaltige Chemiepolitik am Beispiel des Einsatzes von Organozinnverbindungen in der Schifffahrt. In: Angrick M, Kümmerer K, Meinzer L (eds) Nachhaltige Chemie. Metropolis, Marburg, pp 161-172

Watermann B, Ide I, Liebe S, Witten EP (1996) Hämocyteninfiltrationen und Granulocytome in Gastropoden und Bivalviern, Indikatoren für Umweltbelastungen? Deutsche Veterinärmedizinische Gesellschaft, Tagung Königswartha 24-26 September, Verlag der DVG, Gießen, pp 218-229

Watermann B, Ide I, Liebe S (1998) Krankheiten der Miesmuschel an der ostfriesischen Küste. Deutsche In: Wedekind H (eds) Krankheiten der aquatischen Organismen. Tagung der Deutschen Sektion der European Association of Fish Pathologists, Schmallenberg, pp 177-187

Watermann B, Daehne B, Sievers S, Dannenberg R, Overbeke JC, Klijnstra JW, Heemken O (2005) Bioassays and selected chemical analysis of biocide-free antifouling coatings. Chemosphere 60:1530-1541 